\title{
Restorative Justice Policy in Context: A Legal-Archaeological Analysis
}

\section{Giuseppe Maglione ${ }^{1}$ (])}

Published online: 21 July 2020

(c) The Author(s) 2020

\begin{abstract}
This paper provides an original, in-depth analysis of English and Welsh criminal and penal policy on restorative justice. By using a historically-discursive approachlegal archaeology - this study firstly outlines the overarching representations of restorative justice within policy, unpacking their internal organisation. Then, it interprets such patterns of knowledge in light of specific cultural, political and professional transformations involving the Anglo-Welsh criminal justice field over the last 30 years. Along these lines, it generates a historically documented policy map whilst problematising the taken-for-granted images of restorative justice which populate regulations, codes and laws. This has implications for the study of the relationships between restorative justice policy and practice and for future research on the institutionalisation of this 'new' frontier of penality. More generally, the exploration of (unexpected) links between policy, politics and culture, provides material for a critical assessment of how state agencies appropriate community-based and practice-led forms of justice.
\end{abstract}

Keywords Restorative justice · Reparation · Legal archaeology · Discourses · England and Wales

\section{Introduction}

Criminologists and legal scholars have hailed restorative justice $(\mathrm{RJ})$ as one of the most 'significant developments in criminal justice and criminological practice and thinking' [21: 19] over the last 30 years, globally.

Although definitions of RJ are contested [68], there is a recurrent assumption delimiting this concept: people directly involved in a crime should have a say on how to deal with its consequences $[10,132,139]$. Within this framework, 'victims',

Giuseppe Maglione

G.Maglione@napier.ac.uk

1 School of Applied Sciences, Edinburgh Napier University, Sighthill Campus,

Edinburgh EH11 4BN, Scotland, UK 
'offenders' and their 'communities' (e.g. families, relevant others, etc.) are entitled to engage in a constructive dialogue on the harm caused by a crime, in order to achieve material/symbolic reparation leading to psychological healing. The outcome of this dialogue could also have an impact on criminal proceedings (e.g. dropping charge, mitigating sentencing, fulfilling a condition of probation, etc.).

Penal reformers and practitioners alike have often celebrated the involvement of people directly affected by a crime in dealing cooperatively with its consequences, as a long-awaited response to some of the failures of criminal justice [73, 74, 81, 82]. At the same time, both scholars and practitioners have increasingly highlighted conceptual limitations, practical issues and ambiguities of RJ theories and processes $[47,63,106]$.

One of the consequences of such a growing attention from academia and practice, is that RJ has been investigated from multiple theoretical and methodological perspectives. However, whilst the literature is abundant in studies on what RJ 'ought to be' or 'how it works' $[32,87,118,125,139,140]$, there is a lack of engagement with policy on RJ, in spite of the expansion of the normative regulation of this subject [1, 21, 128, cf. 75-77]. Additionally, when policies on RJ are considered, this rarely happens in a theoretically informed, semiotically nuanced, historically documented and critical fashion [103, cf. 78, 79].

This paper, by applying a legal-archaeological framework [37, 38, 40, 102], engages in an original way with the policy on RJ, providing an analysis of the changing representations of RJ within criminal and penal policy documents (inclusive of legal statutes) enacted in England and Wales over the last thirty years [75-77]. Furthermore, it endeavours to insert such discourses in the historical context within which they have emerged. In this way, it is possible to chart the trajectories and rationales of the regulation of RJ in context, reconstructing links between politics, policy and society in this field which have rarely been considered and fully problematised by the academic literature on RJ.

This work is significant for a number of reasons. Firstly, it uncovers the presuppositions and assumptions underpinning policy-making on RJ, shedding light on the rationales of the exclusions and inclusions, emphases and silences which characterise how RJ is designed within normative texts. This may have implications with respect to assessing which images of RJ are imposed top-down to practitioners, which ideas of RJ policy-makers are pushing forward and why. This critical scrutiny is integral to the wider aim pursued by this paper: unpacking a key dimension of the institutionalisation of RJ. In fact, the number of policy documents on RJ has been significantly growing worldwide [68], and there is a need to appraise such a phenomenon critically, without taking for granted its positive effects on the growth of RJ. From this angle, the analysis provided in the second part of this paper enables a nuanced understanding of the cultural, political and professional context within which policy-makers have imagined RJ, tracing original links between professional conflicts, political transformations, scientific discoveries and the incorporation of RJ into policy. In this way, this work generates original insights into both the long-term development and possible trajectories of the institutionalisation of RJ, creating new spaces for research on and critical engagement with RJ. 


\section{Methodological Considerations}

The methodological approach adopted by this study is a re-elaboration of Michel Foucault's archaeology $[37,38,40]$. Foucauldian archaeology is used as a framework for analysing policy in terms of overarching policy discourses [62: 128], i.e. webs of statements conveying ways of thinking and talking (about RJ) through policy documents. Such discourses are reconstructed analytically by 'working backwards' from specific policies, aggregating the most salient (based on the research aims) representations of RJ into larger narratives/patterns of knowledge (i.e. policy discourses). Coherently with the idea that discourse is language beyond the text $[36,38]$, the paper then considers the social and political context [102] within which those ways of thinking and talking about RJ emerged, in order to provide some interpretive keys to make sense of the historical development of those patterns [75-77].

Applying a Foucauldian framework to policy may appear to be incongruous [46: 367, 126: 55], given Foucault's recommendation to look at how power works at the margins of formal institutions. However, sovereignty and its manifestations (e.g. policy), also within a Foucauldian analytical strategy, should not be obliterated. Such an approach, in fact, affords a powerful 'guide for constructing better understandings of legal discourse [...] and how its development over time reflects and shapes cultural change' [102: 349].

In terms of dataset, this study considers the series of public (criminal and penal) policy documents produced in England and Wales between 1985 and 2018 explicitly addressing RJ in domestic criminal justice settings. Internal policy documents from the Home Office, Ministry of Justice and the Crown Prosecution Service were sampled by using The National Archives search engines; the search term used was 'restorative justice', restricting the search to the criminal justice area and to the geo-historical context considered. The dataset was further scaled down on a case-by-case basis by including only regulations whereby there was comprehensive reference to RJ and avoiding duplications. In a limited number of cases, statutes and policy documents with no use of the expression 'restorative justice' were considered, due to their historical role in paving the way for the development of RJ, as acknowledged by literature [20, 29]. Four international documents on RJ for the very same reason were also considered [73: 44-48] $(\mathrm{n}=38)$.

The definitions and descriptions of RJ (its actors, procedures, goals and aims) encoded in the dataset were inductively aggregated based on their thematic commonalities and, as a result, three overarching discourses on RJ were identified [37: 168]. Such discourses are not coherent themes with neat boundaries, but rather analytical tools 'that the researcher projects onto the reality in order to create a framework for the study' [70: 143]. The paper then singles out and discusses the objects, subjects, concepts and strategies which constitute those discourses [37, 38], completing the policy 'archive' of RJ [38: 145].

The next step explores the historical context of the policy discourses on RJ [37: 168]. The aim, here, is to enrich our understanding of those discourses by placing 
them within specific social, cultural, political and professional transformations involving the Anglo-Welsh criminal justice reform field over the last thirty years. In this way it is possible to capture some long-term connections between policy and society which help give meaning critically to the policy regulation of RJ, e.g. unearthing what is taken for granted or silenced by policy-makers.

There are a number of limitations to the research. 'Policy' includes a variety of material written by different subjects, for different audiences and with different goals. The paper tries to differentiate whenever possible such variations. However, since the primary research aim is to discern overarching aspects of the policy on RJ [45: viii], generalisation plays the role of a heuristic strategy coherent with the research aim $[42,106]$. A further limitation is that a gap exists between how specific policies work and their declared objectives. This work does not address the gap between 'policy in the books' and 'policy in action', since it is not a research on 'how RJ works' but an investigation of how policy documents construct RJ. Lastly, the inferences from data are inevitably underdetermined and theory-laden, i.e. many (and possibly incompatible) readings of the same data are possible as well as led by theoretical views [98]. The analyses included in this paper are driven by an intention to address a lack in the RJ literature and identify a direction for critical legal scholarship in this field.

\section{Policy Discourses on Restorative Justice}

It is possible to organise the multiple representations of RJ across policy documents in three main discourses: (1) 'proactive stakeholders'; (2) 'from reparation to restoration'; (3) 'multiple forms of reintegration'.

\subsection{Justice Stakeholding}

The idea of participation and deliberation by lay people in criminal justice has deep historical roots [48]. However, within policy on RJ such an idea is re-shaped in ways that only partially overlap with that well known theme [19].

As acknowledged by both scholarly literature [81, 125, 139] and international policy documents [18: Preamble, 35: art. 1, 3 and 10, 123: 2], one of the most distinctive aspects of $\mathrm{RJ}$ is that this form of justice enables the active participation of the relevant stakeholders (i.e. 'victim', 'community' and 'offender') in the process of handling the consequences of a crime. In English and Welsh policy, RJ is consistently described as enabling inclusion and direct expression of the victim's experience [91: 3, 22: sch. 16.2, 15: 34] whilst empowering the offender and the larger com-munity 'by bringing them into the process and involving them in the solution' of the crime problem [58: 7.33]. An early policy embodiment of this discourse, tangentially related to the development of RJ in England and Wales, was the The Children Act 1989 [122]. This document was used by local charities (e.g. Family Rights Group) as statutory support for the development of Family Group Conferences in England and Wales mainly due to its explicit reference to 'enabling families to take 
up responsibilities, enhancing participation and protection for children and young people and required that the provision of services should be delivered in a partnership with parents' [101].

However, on closer inspection, the idea of 'active participation' appears articulated in different, and at times incompatible, ways for different crime stakeholders. $\mathrm{RJ}$ with respect to victims is fundamentally a process that brings them 'into communication' with offenders [53: 28]. Participation here entails the 'opportunity to talk about, or by other means express experience of, the offending and its impact' [104: 15.3.8] in order to restore their sense of autonomy and safety and 'prevent the feeling of powerlessness which often results from being made a victim' [90: 22]. This is a fundamental objective that RJ tries to achieve [109: 14], opposed to the victims' marginalisation within "conventional" criminal justice, as also claimed by the crime victims' movement since the 1970s [127]. By participating, victims can find answers to some fundamental questions, such as why the crime happened to them, why they responded as they did and what to do in case of re-occurrence. With regard to the idea of community participation, this is particularly highlighted in flagship New Labour criminal policy documents produced between late 1990s and early 2000s such as Justice for All (2002) and The Way Ahead (2001) as well as in laws (particularly the Youth Justice and Criminal Evidence Act 1999). There are two recurrent types of community participation in RJ: by inviting the 'supporters of the victim and the offender' [59: 1.2]; and/or by involving community representatives 'as mediators' [58: 7.33]. The first option entails that the community be involved because of being either victimised by the crime (victim's network) or able to contribute to deal with its aftermath (offender's network). The second route (involving community's representatives) aims to enable community members to play a part in 'searching for local solutions and making the system more responsive locally' [60: 99]. As for offenders' participation, whilst early 2000s documents stressed the assumption of a prospective responsibility, by 'actually honour[ing] their undertaking to make reparations to their victim' [58: 4.12], 2010-2015 documents (mainly published under the Coalition government) particularly emphasised how the offender's participation entails an opportunity to maximise their 'awareness of the impact of the offending concerned on the victims' [104: 15.3.8b, 22: sch. 16.2] and at the same time 'providing an opportunity [...] to face the consequences of their actions' [15: 34]. Responsibility refers to something 'personal' [90: 22], which should genuinely flow from a full awareness of the human costs of the crime, intended as a violation of people's needs, as well as of moral and legal rules.

The idea of 'active participation' is an overarching theme within the RJ field and conversely one of the purported differences with respect to "conventional" criminal justice, even more so in cases of youth offenders [27, 57: 17, 90: 22]. Such a responsibilising approach to participation, embraced by both 1990s and early 2000s documents, was reinforced in normative documents enacted after 2010, although from a slightly different perspective. Here, in fact, participation is framed less as an instrument of community empowerment and more as a strategy of responsibilisation that encourages parties to "take care" of themselves. In RJ, such a strategy is mobilised by asking parties to deal with the crime aftermath by meeting the victim's needs [22: sch. 16.12] in the relevant community. At this point, an underlying tension 
between the victim, community and offender's active participation, stretching across policy documents produced particularly over the last 20 years, arises. It appears, in fact, that the offender's input to the RJ conference is functionalised mainly to the fulfillment of the victim's needs [15: 34], whilst the community is gradually devalued as a crime stakeholder. As it will be clarified in the second part of this paper, these shifts reflect the inconsistencies between different policy-makers' understandings of RJ, characterised by different political, professional and cultural tractions and trajectories.

\subsection{From Reparation to Restoration}

The scholarly literature purports RJ as a process seeking to address the harm caused by the offender to the victim and the community, by material and or symbolic acts of reparation [138: 37]. Reparative schemes were active in England and Wales from the late 1970s [84] and supported by a wide political spectrum [105]. Their goal was to address cooperatively the material harms caused by crime, such as physical damages to the direct and/or indirect victim and community [123, 24, 107]. In this context, reparation was predominantly a diversionary measure for youth offenders administered by police and probation officers, offering little space to the victims' participation and their expression of needs and wants [30, 83, 130]. In the 1980 s a very few reparation initiatives were focussing on victims' needs and these were often framed as 'mediation programs' for adult offenders, influenced by similar experiences from the US $[31,121]$. These were mainly run by voluntary organisations placing emphasis on mediation 'as a process, rather than as a means of delivering a product, such as reparation or diversion' [89: 24]. Seemingly, the slow shift from mediation to reparation, was at least partially due to the work of FIRM (Forum for Initiatives in Reparation and Mediation) founded in 1984, later renamed Mediation UK, which was responsible for the development of good practice guidelines on reparation [89: 24]. In terms of policy documents, 'Reparation: A discussion Document' [55] clearly recognised the awareness for 'psychological and emotional harms suffered by some victims' as a possible drive for overcoming the mere financial goal of compensation, toward a more inclusive concept of reparation.

The widespread development of reparation/referral orders, acknowledged by literature as paving the way for the development of RJ in the UK [29, 73, 99], was announced by the No More Excuses (1997) white paper and then enabled on a national scale by the Crime and Disorder Act 1998 and the Youth Justice and Criminal Evidence Act 1999. In these documents, reparation is a 'constructive' punitive response [23: 67] distinct from mere compensation [136: sch. 5], aiming to responsibilise and reform the offender [56: 4.13]. The community in RJ is a characteristic recipient of the reparation required from the offender, differently from cases of mere victims' compensation or restitution. Reparation to the 'community at large' [23: 67] can be required when 'a victim does not want direct reparation' [56: 4.15], or, more recently, when it is not 'acceptable to the victim' [96: 7.2.16]. This idea of reparation, emphasised both in juvenile and adult criminal justice settings [26: part 
$2]$, rests on the view that the crime 'undermines the social bonds integral to strong communities' [57: Introduction].

A critical discursive shift in the representation of reparation seems to take place over the last decade. During this period, reparation is increasingly framed within policy as an instrument to satisfy the victim, to provide 'closure' [95: 10, 15: 34] 'enabl[ing] the victim to move on' [97: 3]. Victims are entitled to obtain reparation [109: 6, 94: 2, 104: 15.8, 111: 1] in order to heal interpersonal bonds corroded by crime. The harm here is not only the material loss or damage but also (and characteristically) the symbolic harm. This expression refers to the offender's breach of 'relationships and trust' with the victim [59: 1.1], by creating a sense of fear and lack of safety. Apology or community work are considered typical symbolic reparations since they are supposedly apt to mend the relational bond between parties damaged by the crime [11: 115]. Furthermore, from the offender's side, the active participation in the RJ process, the expression of remorse, listening and responding to the victim, are all activities integral to symbolic harm repair [59: 3.7]. This partial 'dematerialisation' of reparation can be interpreted as a symptom of the slow discursive fluctuation from 'reparative justice' (enshrined in British legislation since compensation and restitution orders [24: 1-6] and implemented by probation services) [132: 50] to 'restorative justice'. In the latter, material and symbolic repair are described as being functionally linked [92: 14, 97: 3] and directed to fulfill victim's needs [110: 1]. From this perspective, without the symbolic repair, it may be difficult to achieve agreement about material reparation [112]. The settlement (i.e. victim acceptance of the offender's harm repair) depends on the visible repentance shown by the offender during the RJ process.

\subsection{Restorative Reintegration}

Restorative reintegration, that is, the offender's return to the larger community after their "redemptive" journey through RJ, is a key goal pursued by policy on RJ [56: 9.21, 90: 30, 54: 4]. Namely, restorative reintegration means 'paying their debt to society, putting their crime behind them and rejoining the law abiding community' [56: 9.21]. Late 1990s policy documents showed coherence with the theory of 'reintegrative shaming' [10] with respect to representing reintegration. The offender's 'shaming' and meaningful involvement in the decision-making process [59: 3.7] are reintegrative insofar as they are community-based processes and not marginalising and stigmatising mechanisms. The very attendance of a RJ encounter represents a symbolic moment of reintegration as re-acceptance of the offender within the civic dialogue. In this context, reintegration refers to the offender's incorporation into a community-based prosocial moral order [61: 1.9] to be achieved within the RJ meeting, symbolically (the fact of taking part) and psychologically (e.g. reintegrative shaming). It is possible to map out two main forms of restorative reintegration: into the micro-social community (material/psychological repair of damaged social relationships with the victim) and into the macro setting (dialogue between the family members or parties networks). Restorative reintegration then entails both a material engagement with the other stakeholders (victim and community) and a symbolic 
're-entry' in the moral/legal order. This idea of reintegration is linked to the responsibilities that the community holds when a crime occurs, both toward the victim and toward the offender as well as to the assumption 'that crime has its origins in social conditions and relationships in community' [82: 6].

Whilst late 1990s documents consistently stressed the idea of offender's reintegration through RJ as a means to re-generate community ties [5: 7, 56: 9.21, 23 (guidance document): 2.1-2.4], in the Coalition's policy papers, restorative reintegration was represented as strategic in deterring the offender from committing future crimes [90: 30, 54: 4, 93: 7] in a wider context of 'protecting the community' [2: part 4] and satisfying the victim [92: 14].

\section{Unpacking the Policy Discourses on Restorative Justice}

This section looks at the internal organisation of the policy discourses on RJ. Following Foucault [38], the research singles out the relevant discursive objects, enunciative modalities (i.e. subjects), concepts and discursive strategies.

\subsection{Objects}

A discursive 'object' is what a discourse is systematically talking about [38: 40]. Such objects do not preexist discourses, being instead shaped within them. From this perspective, the two main (and interrelated) objects of policy on RJ are 'crime', uniquely construed as legal expression of non-functioning interpersonal relationships, and 'harm', that is, the human consequences of legal transgressions. The crime is a wrongful behaviour since it harms the material victim and/or the community; accordingly, the expected outcome of a RJ process is the reparation of harm and reintegration into the community (especially in 1990s documents) as well as the maximisation of the offender's awareness of the crime's impact and the victims' empowerment (2000s documents). Both discursive objects are underpinned by the idea that legal transgressions are the expression of conflictual relationships which "belong" (also) to their direct actors, who are entitled to have a say in managing the crime/harm's consequences. At the same time, crime remains a public wrong, insofar as the harm has a public relevance, justifying the criminalisation. It is irrelevant under which circumstances behaviours are labelled as crimes. It is accepted that certain actions are criminal, implicitly endorsing both primary and secondary criminalisation. If one participant contests the nature of 'crime/harm' of their action, that would automatically exclude that person from participating in the restorative encounter [25: 22]. Within policy documents enacted over the last decade, RJ is particularly portrayed as a response to crimes/harms by focussing on whole persons, their relationships and the whole of the problem, emphasising claims about offering material repair, responsibilising offenders and providing closure for victims.

A further object is "conventional" criminal justice. This is not a content-rich signifier, with defined conceptual boundaries, but a support of the definition of RJ, a means to stabilise RJ from outside [51: 43]. "Conventional" criminal justice 
identifies a strategic backdrop against which RJ is consistently described. In this context, RJ is considered a response to needs triggered by the (dis)functioning of criminal justice. It is worth noting that policy does not construe "conventional" criminal justice as a competitor of RJ. Instead, RJ appears as a 'new' instrument meant to enrich Leviathan's justice toolbox, in this way silencing critical criminologists' understandings of RJ as a radical alternative to criminal justice [e.g. 67, 69]. "Conventional" criminal justice here includes the idea of penal retribution, without however coinciding with it. The former, in fact, is shaped within policy on RJ as a broad legal rationality centered on individual responsibility, justified in the name of public order, implemented by (sometimes dysfunctioning) public bodies. Retribution is only a component of this rationality and RJ seems to integrate from outside retribution, mainly by responsibilising the offender.

\subsection{Subjects}

'Victims', 'offenders' and 'communities' are the main subjects within policy discourses on RJ, since they bind together statements on RJ [38: 50]. Once again, these are not taken-for-granted entities defined by their internal nature. Instead, they work as subject positions (i.e. repertoires of dispositions and conducts) construed within those discourses mainly through classification, norm-setting and foregrounding/backgrounding practices [41: 208]. The 'victim' was an elusive subject in reparative measures until the late 1990s and conceptualised as a recipient of material reparation, whose needs were not explicitly identified. This subject re-entered the criminal justice scene thanks (mainly) to New Labour legislation, appearing as an increasingly central subject in 2000s documents. Here, it was portrayed as a two-faced subject: on one hand, an agentic and resilient individual undertaking decisions and actions; on the other, a disempowered and embodied entity, in search of safety and recognition. Whilst reparative measures designed between late 1970s and 1990s, were merely meant to "fix" the material consequences of crime, contemporary RJ offers the victim a proactive agency-based solution to victimisation. The 'offender' in RJ exemplifies a wrongdoer who harms a discrete victim often due to a lack of emotional understanding and moral maturity [50]. Shining through policy is the image, relatively unchanged over the last 30 years, of a 'wayward child' [131], to be reprimanded and reformed. The community's ties with such an offender are weak, but still exerting forms of control over them. This offender (like the victim) is a flesh-and-blood individual encouraged to "pay back" the human costs of their actions. This representation ignores the possible macro-constraints of the offender's actions as well as the fluid relations between these two dimensions, emphasising a distinctive type of agency and conveying images of physical harm. Additionally, the possibility of a shared responsibility with the victim is obliterated. Finally, the 'community' of RJ is construed as a law-abiding collective subject, whose boundaries are relatively blurred. 'Community' is the local alternative to 'state' and 'society', a resilient and fusional actor harmed by crimes. Such an actor was particularly 
emphasised within late 1990s policy produced by the New Labour government, whilst during following years, it appears as being downplayed in favour of a more central victim, positioned as the recipient of 'restoration'.

RJ discourses organise (i.e. 'make up') people into such subject positions by pre-setting their needs, wants and desires. It is arguable that such positions do not properly fit many types of individuals with a stake in a crime. Collective victims of economic crimes, powerful victims, victims with shared responsibility, vulnerable offenders and deviant communities are types of stakeholders hardly consistent with the ideal subjects of RJ [75-77]. Consequently, problems in terms of proposing and practising RJ for these latter categories may likely arise.

\subsection{Concepts}

'Concepts' are the principles around which the normative statements on RJ are organised [38: 56], defining the very architecture of discourses. The main organising principle here is the very concept of 'restoration'. Such an idea seemed to absorb and overcome, during the 1990s, the concept of 'reparation' as a mere material fixing of the crime consequences. Reparation is not ruled out from RJ, but rather reframed as performing new functions and fulfilling new needs. The concept of 'restoration' is characterised by a few recurrent traits: (1) holistic; (2) needs-based; (3) emotionally intelligent.

'Restoration' is a holistic and needs-based gain for the crime stakeholders. This means that the different aims of RJ are often presented as being intimately interconnected: symbolic and material, moral and psychological, individual and social elements coalesce around the ideal outcome of RJ, transcending cultural, social and personal differences [43]. This idea refers to the purported capacity of RJ to satisfy the stakeholders' needs ingrained in their human nature: safety, justice, participation and empowerment. The discourses highlighted above do not revolve around stakeholders' interests, rights or entitlements, but needs: universal or natural requirements of the person/community harmed by a crime. Arguably, satisfying different stakeholders-by e.g. active participation, healing, reparations, etc.-may generate tensions which could not be easily neutralised, unless by prioritising certain stakeholders over others. This appears to be the case of policy documents on RJ produced over the last 15 years: the focus has increasingly been the victim, whilst the community has been evoked as the ideal backdrop of victim-centered initiatives and the offender as a de-responsibilised actor. The idea of empowering crime stakeholders, whilst often summoned by policy documents as one of the main differences with respect to "conventional" criminal justice, would be better described as an attempt to fulfil ideal victims' needs and responsibilise offenders. Finally, 'restoration' consists of a menu of solutions inspired by a criminological doxa which presents itself as emotionally intelligent $[78,79]$. The focus on healing, closure and personal transformation represents an effort to address the limitations of contemporary criminal justice, by setting up a form of justice more emotionally responsive to individual needs. 


\subsection{Strategies}

'Strategies' in this context refers to 'certain organizations of concepts, certain groupings of objects, certain types of enunciation, which form, according to their degree of coherence, rigour, and stability, themes or theories' [38: 64]. They are intertextual constructions which work to fix the meaning of concepts, objects and subject positions.

From this angle, RJ enshrined in legislation/policy embraces a functionalist approach to crime [129: 97] which glues together objects, subjects and concepts. Crime is seen as a social pathology which needs to be neutralised. RJ aspires to "cure" this pathology, by healing the victim and transforming the offender, whilst neglecting both the emancipatory potential of transgressions of established legal frameworks and the unbalanced power relationships which contribute toward the definition of behaviours as crimes. Such language is configured as being rooted in human nature, and as such valid beyond space and time.

At the same time, RJ dichotomises the relationship between crime stakeholders, shaping it as an oppositional relationship between atomic parties, individually responsible for their positions. This entails the correlative definition of power relationships between the same actors, as essentially unbalanced and dichotomous, but also depending on their will/choice, and therefore amenable to resolution or transformation. RJ shapes crime stakeholders as 'embodied' actors, that is, clearly identifiable and definite individuals harmed or able to harm. The idea of "disembodied" crime stakeholders (e.g. corporations or states) is alien to RJ; RJ produces and addresses only human, flesh-and-blood actors [75-77]. To such actors, RJ provides mainly emotional gratification, whilst neglecting long-term material commitment and support [88]. Additionally, the actors of RJ are organised as 'exclusive' subject positions. Victims and offenders are construed as ontologically different. This approach to crime stakeholders embedded in policy, emphasises their being morally deficient yet morally responsible: they are emotionally involved and psychologically affected; for this reason, stakeholders are in need of being directed from outside (by the facilitator). However, if the RJ process does not achieve 'restoration' it will be their own responsibility.

\section{Historical Contextualisation}

This section aims to understand the discourses outlined and unpacked above in light of the historical context within which policy on RJ has emerged [37: 168]. The focus is placed on the political, cultural and professional fields [38: 41] within which a range of social actors [38: 41] involved in reforming criminal justice in the UK have contributed to create the conditions for the emergence of the policy on RJ [38: 42].

\subsection{Probation Services and Offender Organisations: Change and Decline}

Youth probation organisations have campaigned for and implemented, since the late 1970s, projects of 'mediation' and 'reparation' for youth crime and anti-social behaviour. Early precursors of RJ programs in the UK 'began in isolated cases when 
individual probation officers or social workers perceived suitable opportunities in the normal course of their casework' [81: 22]. Probation services have traditionally advocated for a "welfarist" understanding of reparation [8: 267] linked with diversion, mitigation and offender re-education, combined with the ideas of penal minimalism and 'civilising' criminal justice [14, 52, 131]. This view was injected at the heart of reparative initiatives for minor youth criminals in the 1980s [74: 40], remaining a constant component of $\mathrm{RJ}$ as a diversionary intervention for youth offenders throughout the 1990s [29]. The main point here, is that probation agencies developed, between the early 1980s and the 1990s, a (youth) offender-focussed approach to RJ, promoting transformative reparation initiatives tailored on the offender's needs, even though the victim did have a role as recipient of practical and symbolic reparation [84: 39]. This perspective is overlapping with offender organisations' understanding of (and advocacy for) RJ for young people. Particularly, the National Association for the Care and Resettlement of Offenders' report 'Responsibility, Restoration and Reintegration: A New Three R's for Young Offenders' [100] has been recognised as one of the inspirations for the reparative measures introduced within the Crime and Disorder Act 1998 and the Youth Justice and Criminal Evidence Act 1999 [99: 170]. Both perspectives were critical of the retributive approach to youth crime, defining reparation as a prosocial activity related to the offender's responsibilisation (ending the 'excuse culture') and reintegration, more than to the victim's needs [114: 289]. The Crime and Disorder Act 1998 and the Youth Justice and Criminal Evidence Act 1999, whilst receiving those converging perspectives, 'recontextualised' [36: 89] (and altered) probation's original aims, by adding a number of further elements, such as the 'communitarian' nature of reparation [135]; a contractual element in delivering justice [20] and an incipient attention to the crime victim as consumer of justice [50] In this (New Labour) context, emphasis is placed on the creation of community-based decision-making panels and on responsibilising contracts for (youth) offenders [20]. Additionally, increasing attention is paid to the crime victim's involvement in the justice process [136: 23.7]. Overall, it seems that the discourse of 'active participation' and responsibilisation of (youth) offenders through reparation are expressions of the partial incorporation of probation/offender organisations' claims into New Labour flagship criminal laws in the late 1990s.

This relevant but limited (and decreasing) impact of probation/offender organisations on the policy representations of RJ has been further influenced by the internal overhaul (and weakening) of probation services in England and Wales since the 1990s. Arguably, the shift from 'probation' to 'offender management' has entailed a growing focus on managerialist modes, at odds with original rehabilitative ideals. This has led probation officers to increasingly see RJ as a fast-track low-threshold form of justice [16: 133] and less as a rehabilitative community-based measure.

\subsection{Religious Influences}

Probation officers' interest in reparation and mediation in the 1980s benefited from exchanges with organisations gathering professionals, academics and members of religious groups external to the British context [81, 121]. Well documented 
exchanges involved overseas police forces. This is the case of the connection between Terry O'Connell (advocate of RJ based on reintegrative shaming principles) from Australia and Thames Valley Chief Constable Charles Pollard which triggered the development of pioneering RJ initiatives in the area [28]. Religious groups (especially Quakers and Mennonites, United Methodist Church, Prison Fellowship) have contributed to the practice of reparation and then RJ since the 1970s, in the US, Canada and then UK [7: 252, 85: 7]. The literature has widely accepted that the 'first experiment' of modern victim-offender mediation was run by and within a Mennonite community, in Canada [68]. From this marginal experience a model of dealing with youth crimes was singled out, based on face-to-face meetings between victims and offenders to explore interpersonal reconciliation and reparation (i.e. Victim/Offender Reconciliation Program). This was imported into the UK by US scholars and practitioners in the early 1980s [73]. Parallely to the slow diffusion of such programs, academics/practitioners started 'rationalising' these innovative practices blossomed at the margins of criminal justice systems. Howard Zehr (one of the main advocates of RJ in the US), himself a Mennonite, played a crucial role in this context. Zehr's main contribution was perhaps to emphasise numerous parallels between RJ and spirituality, stressing in this way the outreach potential of RJ for both offenders and victims. RJ resonates with spiritual elements such as human interconnectedness, reconciliation, and fulfillment of basic human needs [137, 139]. Such principles are presented as a-historical and a-ideological, that is, universal [7: 253]. These spiritual/academic outsiders have influenced the language of RJ in multiple ways, mainly through exchanges with probation officers and by running reparative/restorative schemes [74]. Additionally, in the UK religious organisations similar to those active in North America have also contributed directly to the development of a cultural platform for RJ. This is the case of the Christian-inspired Jubilee Policy Group, whose perhaps most significant intervention in this field was the publication of the well known edited collection 'Relational Justice' [13] which contended that 'a central goal of the criminal justice system should be to make every effort to repair the relationship between offender and victim' [13: 50].

The diffusion of ideas of personal transformation through remorse, forgiveness and reconciliation help understand the discursive shift from rehabilitative reparation to the concept of 'restoration' in the late 1990s. The 'transformational' aim of RJ, often evoked in the Coalition's policy, seems to echo this language, whereby reduction of reoffending is an expression of personal transformation and maximisation of awareness for one's behaviours.

\subsection{Victims' Movement and Victimology: Institutionalising the 'Return of the Victim'}

Victims' organisations have participated in the discursive production of RJ, with a number of actions ranging from pioneering advocacy for a victim-sensitive justice [44] to setting some reparation services [113]. In England and Wales, victims support organisations stemmed from early 1970s discussions within offenders associations, namely the Bristol Association for the Care and Resettlement 
of Offenders (a NACRO local branch), on the possibility of helping offenders to become more aware of the harm they were doing, by introducing them to their victims [73: 25]. This led to the first Victim Support Scheme in Bristol in 1974, which meant to investigate what victims of crime wanted. Differently from youth probation agencies, victims' organisations concentrated also on the relational side of the crime, focussing on victims' multiple material and psychological needs and on complex victim-led interventions (often exceeding 'reparation'). Historically, in fact, victims' organisations' support for the idea of repairing the harm of crime, has been 'cautious' [133: 656]. Early reparation and mediation projects in the UK and US in the late 1970s were seen with ambivalence by victims' organisations, due to their apparent link with probation-led, offender-centered initiatives [29]. The typical objection raised was that since reparation and mediation mainly seek to achieve 'crime reduction and the re-education of the offender' [133: 657], they are not acceptable alternatives to prosecution or sentencing, actually they are a 'new distraction' from the support and protection of victims' needs [114: 294]. However, it was usually acknowledged that reparation and mediation 'in their own right' i.e. as post-sentencing or post-release options, could fulfil certain victims' needs [108: 138]. Over the years, victims' associations have slowly embraced reparative interventions (more than mediation ones), by shaping them as victim-centered 'restorative' schemes requiring the admission of responsibility of the offender, denying any fact-finding role to restorative encounters. This viewpoint has been finally codified by the EU Directive on Victims' Rights 29/12 (art. 12 describes RJ as a 'victims' service'). For victims' organisations, RJ is a penal mechanism whose goal is to empower the victim and then responsibilise the offender. The relationships between the 'return' of the victim's voice [45: 11] as academic subject, media phenomenon and political resource, and RJ have been persuasively established [81:23]. As stated above, crime victims' direct involvement in criminal justice and the claim of meeting their needs, have become key categories in the normative language of RJ. Such claims have been academically backed up by a 'new' victimology, advocating for a crucial shift from a rightsbased to a needs-based way of understanding and supporting crime victims and conveyed by extensive media campaigns $[116,117,80]$. The ideas of victim's restoration through active participation as well as the very claim to encounter the offender in order to receive healing/closure, seem informed and enabled by the popularisation of the 'return of the victim'.

A further component of this cultural platform has been the process of progressive transformation of victims in consumers of justice [114]. Namely, the Victims Charter 1990 and 1996 and following updates, embodied the idea of treating victims as consumers of justice, by e.g. shaping the definition of standards regulating the relationship between justice institutions and victims on the model service-provider/ customer relation or by reconceptualising the British Crime Survey as 'an instrument to measure performance and consumer contentment with the criminal justice' [115: 336]. Issues such as 'having a say' regarding the functioning of democratised public services (the rise of Victim Impact Statements can be also read from this perspective) and the need of receiving information have become in this context critical demands put forth by victims' organisations. 
The language used by policymakers to define the aims of RJ since the late 1990s shows similarities with certain themes (e.g. victim's "neglect" in criminal justice, 'having a say', information rights) that consistently feature in the victims' organisation discourses on justice. From this perspective, over the last 10 years RJ has been increasingly conceptualised as a 'victim-centered' penal justice.

\subsection{Janus-Faced Policing}

The normative language of $\mathrm{RJ}$ is possibly indebted to a further group, who, over the last 30 years, has been able to re-produce a distinctive practice-based knowledge on RJ. Police have been involved in the deployment of reparation projects since the late 1970s $[29,73]$. In these early days, police would caution young offenders and refer them to local social services in order to enable a reparation activity [89: 24]. Later on, the pioneering practices of Thames Valley Police in the 1990s offered further evidence for the introduction of RJ measures into the Crime and Disorder Act 1998 and the Youth Justice and Criminal Evidence Act 1999 [64]. One of the "merits" of the Thames Valley Police was to import to the UK the 'reintegrative shaming' approach developed by John Braithwaite [74: 42]. Since then, RJ processes based on the theory of reintegrative shaming have been used by many other UK police forces 'so that in the UK, RJ has come to be identified for many years with Braithwaite's theory of reintegrative shaming' [68: 4]. Interestingly, the diffusion of reintegrative shaming entails a reframing of 'reparation' measures as 'restorative' interventions, an effect similar to and somehow overlapping with the impact of victims' support narratives on RJ, with one obvious difference: the target of shaming is the offender, not the victim. However, the victim does not disappear from police-led RJ. Actually, RJ is perceived to play an important role also for the victims, mainly in terms of enhancing police-victim relationships [114: 303]. RJ applying reintegrative shaming appears as a preventative more than punitive response, yet constructive, for the alleged offender [61: 1.9] which resonates with community policing philosophy insofar as it (putatively) contributes toward restoring links between police and the community. Additionally, over the last decade, RJ has become particularly appealing to the police for another reason: its likeness to a cost-effective 'commonsense' justice mechanism [3, 4].

Overall, this police-led approach to RJ appears as two-faced. Firstly, RJ is a deformalised moralising strategy for dealing with minor (youth) crimes. Secondly, it is a street-level conflict management option characterised by a lack of procedural safeguards and speedy proceedings. This representation of RJ resonates with both the language of early reparative measures (as informal responses to minor crimes) and with New Labour community-based moral discipline and multi-agency interventions, as well as with the Coalition's documents which emphasise the need for efficiently delivered justice.

\subsection{Shifting Criminological Imaginaries}

Criminologists have played a role in delimiting the field of RJ and in producing knowledge to be translated into policy instruments. The cultural landscape within 
which the concept of community-based 'restoration' arose, in the late 1990s, was particularly characterised by the development of 'third way' criminologies, inclusive of cultural strands as different as left realism and civic criminologies [66: 23]. Left realism's attention to community-based and multi-agency interventions [72] and civic criminologies' emphasis on the idea of crime as an effect of the erosion of the moral structure of local communities [10-12, 32], have contributed, inter alia, toward the promotion of social integration and civic participation in dealing with crime control. Victims and offenders are thought of as being entwined in social interdependencies whose symbolic significance takes priority over individual interests [10: 100]. The offender in particular, is conceptualised as breaching the trust which ties them and the victim together within a supposedly shared community. These criminological approaches, resonating with New Labour's 'third way' doxa [49] proposing community-based moralising and responsibilising interventions [64], have provided RJ with 'an intellectual authority and practical methodology' [114: 297]. Over the years, they have absorbed (and silenced) the fluid discourse of 'civilising' criminal justice which emerged in the 1980s, informing probation officers' early work on reparation [9: 84]. In England and Wales this discourse has historically entailed emphasis on restitution, compensation and mediation in criminal matters $[14,52,131,134]$. In this context, crimes were thought of as problematic situations or conflicts to be mediated and handled by involving the direct stakeholders. Whilst the broad idea of involving crime stakeholders has gained currency in contemporary RJ, the replacement of 'crime' with 'conflict' and the idea of mediation/dispute resolution arenas alternative to criminal proceedings, advocated by the penal abolitionists [e.g. 67], have been contested by victims' movements and never received by Anglo-Welsh policy-makers.

\subsection{Centralised Political Change and Criminal and Penal Policy}

Political parties have contributed toward shaping RJ by receiving, re-elaborating and translating other social actors' understandings of RJ into policy. Additionally, many of the organisational changes imposed upon e.g. probation services or the police with an impact on the theory and practice of RJ, have been driven by political groups themselves. The British Conservative Government in the 1980s sponsored reparation schemes as a 'cheap alternative to fine and imprisonment' [114: 294], funding demonstration projects, which however then turned out as less cheap than Conservatives hoped for [55]. However, as already seen, the main political actor here was New Labour during the second half of the 1990s-early 2000s. The normative language of RJ, and especially the slow shift from an offender-centered 'reparative justice' to a community-based and then victim-led 'restorative justice', seems informed by certain themes characterising the moral communitarianism embraced by New Labour [21: 17, 63: 34]. This approach assumes a permanent tension between state, individuals and society and promotes social responsibility and policies in order to stop the erosion of communal life in an increasingly fragmented society [71]. It tries to respond to the collapse of moral fabric caused by liberalism as well as by the left. This response consists of investing in (or perhaps creating) the community as moral 
infrastructure of human character [34, 49]. Such a 'community' is a normative fiction which supposedly coheres individual interests and social needs, often in a subtly authoritarian and disciplinary way [119], whilst backing up a trend toward managerialisation and centralisation [86: 213]. Such a rhetoric is accompanied, within the criminal policy domain, by an attempt to put the 'law-abiding citizen' (i.e. the victim) at the center of the criminal justice system [6: 198]. This approach drove New Labour multi-agency interventions on anti-social behaviours and minor crimes, paving the way for the use of the 'victim's community' as an ideal space of crime control [66: 73]. On one hand, this translated into the popularisation of the ideas of citizens as 'partners against crime' [45: 205]. On the other, it led to the political exploitation of the crime victim as an ideal citizen. The emergence of such conceptual apparatus, resonating with 'third way' criminologies and the new victimology, has been critical for the development of RJ in England and Wales, and especially for the concept of 'active participation', for the ideas of 'community' and 'victim' as crime stakeholders and for the shift from 'reparation' to 'restoration'.

New Labour's contributions to RJ were further developed during the 'Coalition era'. Particularly, the Coalition's normative documents appeared to strengthen the focus on the victim and emphasise the efficiency of RJ, whilst the community was absorbed by the 'Big Society' narrative [17]. Legal statutes and policy documents enacted in this period, such as the Offender Rehabilitation Act 2014, Breaking the Cycle (2010), Facing Up To Offending (2012) Swift Justice (2012) and the new Victims Code (2015) shaped RJ as a 'swift justice' tool for low-level crimes, aiming to satisfy victims as consumers of justice and re-moralise offenders [33, 120]. The main (perhaps paradoxical) difference compared to New Labour, was a partial return to localism in the provision of victims services, including RJ, by allocating to Police and Crime Commissioners (PCCs) the competence to fund RJ services in a 'locally responsive' way [92: 16].

\section{A regime of Truth: Tensions, Overlaps and Intersections}

The cultural, social and political landscape within which the policy on RJ has emerged is characterised by both tensions and combinations [38: 65], expressive of the power relationships among the different actors involved in that context. These dynamic interrelations can be conceptualised as a 'regime of truth' [39: 23], a fluid system of multiple constraints, which underlies the discourses discussed above.

A particular tension emerges between the enunciative modalities of 'victim' and 'offender'. As already mentioned, the progressive strengthening of crime victim's movements in the UK and the parallel weakening of 'welfarist' probation service, led by New Labour and then by the Coalition government, has filtered into policy producing one main effect: the portrayal of the offender's needs/wants as embedded in the community and functionalised to those of the victim. The offender appears as the victim's counterpart, silenced by expert discourses, 'reintegratively' shamed and led to repair. The victim's needs are consistent with the victimological research findings and the crime victims' movements' claims, at least since the late 1990s. As a consequence, the idea of restoration-as-offender-reintegration is weakened in spite 
of the strengthening of the notion of restoration-as-offender-responsibilisation and then restoration-as-victim-satisfaction. This tension was not only related to the political rise/decline of these two groups, but also to their different cultural backgrounds rooted in penal minimalist approaches [e.g. 131] (probation services) and victimological knowledge (victims' movements) [113]. In fact, victimological research takes for granted what penal minimalism deeply deconstructs: the concept of crime. In penal minimalism, deprofessionalisation of social control and crime as problematic situations are basic tenets. Conversely, the victimological discourse implies the regulative presence of experts, creating a vertical way of regulating social conflicts, which, as a consequence of this expert intervention, are often configured as inner (psychological) conflicts. This epistemic shift in construing the objects of RJ is related to the tensions between those two discursive producers of RJ [38: 69]. Additionally, whilst penal minimalism is relatively incompatible with New Labour's moral-communitarianism and the Coalition's managerialism, victims' movements' claims have exerted a bipartisan appeal.

Clearly, also combinations are present. From this perspective, 'third way' criminologies (namely reintegrative shaming) resonate with both New Labour moral communitarianism and with the police search for swift interventions with a punitive-re-moralising effect [47: 67], supported also by the Coalition's policy papers. In a similar vein, the 'community' evoked by New Labour in policy documents on $\mathrm{RJ}$ is mainly a reformulation of the (ideal) victim's community (socialised, middleclass, resilient) evoked by victim's support groups.

These relationships identify multiple slippage(s) within policy discourses on $\mathrm{RJ}$, possibly creating the conditions for multiple interpretations of RJ at the point of implementation-i.e. in practice. Historically, the "geological depth" of RJ has been one of the conditions for both the differentiated provision of RJ and the slow but increasing incorporation of RJ into English and Welsh criminal justice. RJ has attracted a wide spectrum of political and social actors due to its multiple rationales. Yet, the impossibility to completely identify this policy option with either political/ social actors' agenda, has possibly run counter to its further popularisation. Within such a landscape, the 'return of the victim' as a media, political and academic mainstream phenomenon over the last 20 years, has modified the economy of this regime of truth. The victim's movement has increasingly achieved epistemic/political primacy over other actors, playing a progressively central role in ruling in and out ways of thinking and talking within RJ, defining legitimate versions of this form of justice. The structural incoherence of RJ, whilst still a feature of this layered field, is therefore mitigated by the emphasis on victim-centered aims and goals. Until the victim-as-ideal-citizen will exert a bipartisan appeal to political actors, a victimcentered RJ will keep a central position within English and Welsh legislation. Then, whether and to what extent this type of RJ will actually be implemented, informing RJ services' daily work, this will largely depend on organisational models, RJ practitioners' culture and training and other specific contextual factors that only empirical research can chart. What appears as evident, here, is that within a context where political differences between main parties tend to be erased and politics as social contestation fades away, the 'crime victim', as a 'hollow signifier' devoid of social 
context [88: 107], appears to embody moral cohesiveness, and as such becomes a catalyst for a wide political consensus.

\section{Concluding Remarks}

Incorporating RJ into policy entails a number of discursive exclusions and inclusions, emphases and silences. As this paper has shown, policy in England and Wales shapes RJ around certain objects, subjects, concepts and strategies. This discursive formation has emerged within a distinctive historical context characterised by the weakening of state-based probation services, the increasing political appeal of victims' organisations, the rise and decline of moral communitarian claims and by demands for 'managerialising' criminal justice.

Over the last 30 years RJ has been described as seeking to satisfy victims' needs for security and healing, to enable offenders' empowerment and to reduce re-offending by investing in individual agency within communitarian settings. However, the politicisation of the 'return of the victim', over the last 20 years, has partially redefined RJ as a victim-centered penal policy option, subjugating other claims and aims injected at the heart of RJ over time, by multiple actors. Contemporary RJ imports into the criminal and penal policy arena a vocabulary which emphasises self-regulation, neglects socio-structural constraints of criminalisation processes, and focuses uniquely on the subjective agency as a crime context and as a site of victims' 'restoration'.

From this perspective, it is worth considering that some of RJ's most progressive motifs emphasised by the scholarly literature [69] (e.g. informality, conflict reappropriation, dismissal of the state, rejection of the "conventional" criminal justice language), are silenced within policy discourses of RJ. This may lead to a rethinking of the effects of incorporating RJ into policy frameworks.

The paper also recommends further research in at least two directions. Firstly, empirical studies on how practitioners and stakeholders interpret, negotiate and reframe the policy on RJ. The implementation of policy frameworks entails the reproduction of (other and possibly diverging) discourses. Additionally, considering the continuity between Labour and Conservative understandings of RJ, it would be necessary to further excavate the political drives of RJ, within the Anglo-Welsh context, rather than only considering political parties' agendas. The original, finegrained unpacking of RJ offered by this work may provide a benchmark against which to compare the 'practical discourses' of RJ and a useful reference for those interested in studying the politics of RJ policy.

More generally, this paper suggests responding critically to the transformation of $\mathrm{RJ}$ into a criminal and penal policy option. Policy-makers construe RJ according to specific, politically-driven and culturally informed categories which shape the "version' of RJ which is proffered to providers, practitioners and stakeholders. New policies on RJ should be carefully scrutinised since there is nothing neutral (and natural) in how (and why) Leviathan appropriates an originally community-based and practice-led form of justice. 
Acknowledgements I wrote part of this paper during a stay as visiting researcher at Durham Law School, Durham University. I wish to thank Professor Thom Brooks for the kind hospitality and precious insights and the library staff for their help. I also wish to thank Kirsty Boutle for her encouragement in writing this paper.

Open Access This article is licensed under a Creative Commons Attribution 4.0 International License, which permits use, sharing, adaptation, distribution and reproduction in any medium or format, as long as you give appropriate credit to the original author(s) and the source, provide a link to the Creative Commons licence, and indicate if changes were made. The images or other third party material in this article are included in the article's Creative Commons licence, unless indicated otherwise in a credit line to the material. If material is not included in the article's Creative Commons licence and your intended use is not permitted by statutory regulation or exceeds the permitted use, you will need to obtain permission directly from the copyright holder. To view a copy of this licence, visit http://creativecommons.org/licen ses/by/4.0/.

\section{References}

1. Aertsen, Ivo, Tom Daems, and Luc Robert (eds.). 2006. Institutionalizing Restorative Justice. Cullompton: Willan Publishing.

2. Anti-social Behaviour, Crime and Policing Act 2014 England and Wales. http://www.legislatio n.gov.uk/ukpga/2014/12/contents/enacted. Accessed 6 July 2019.

3. Association of Chief Police Officers (ACPO). 2011. Restorative justice guidance and minimum standards. https://www.restorativejustice.org.uk/sites/default/files/resources/files/ACPO\%20res torative $\% 20$ justice $\% 20$ guidance $\% 20$ and $\% 20$ minimum $\% 20$ standards.pdf. Accessed 17 October 2019.

4. Association of Chief Police Officers (ACPO). 2012. Guidelines on the use of Community Resolutions (CR) incorporating Restorative Justice (RJ). http://library.college.police.uk/docs/appref/ Community-Resolutions-Incorporating-RJ-Final-Aug-2012-2.pdf. Accessed 17 October 2019.

5. Audit Commission. 1996. Misspent Youth. Young People and Crime. London: Audit Commission.

6. Bell, Emma. 2011. Criminal Justice and Neoliberalism. London: Palgrave.

7. Bender, Kimberly, and Marilyn Armour. 2007. The Spiritual Components of Restorative Justice. Victims \& Offenders 2 (3): 251-267.

8. Blagg, Harry. 1985. Reparation and Justice for Juveniles. The Corby Experience. British Journal of Criminology 25 (7): 267-279.

9. Bottoms, Anthony. 2003. Some Sociological Reflections on Restorative Justice. In Restorative Justice and Criminal Justice: Competing or Reconcilable Paradigms?, ed. Andrew von Hirsch et al., 79-114. London: Hart.

10. Braithwaite, John. 1989. Crime, Shame and Reintegration. Cambridge: Cambridge University Press.

11. Braithwaite, John. 2000. Repentance Rituals and Restorative Justice. Journal of Political Philosophy 8 (1): 115-131.

12. Braithwaite, John, and Philip Pettit. 1990. Not Just Deserts: A Republican Theory of Justice. Oxford: Oxford University Press.

13. Burnside, Jonathan, and Nicola Baker (eds.). 1994. Relational Justice: Repairing the Breach. Winchester: Waterside Press.

14. Christie, Nils. 1977. Conflicts as Property. British Journal of Criminology 17 (1): 1-15.

15. Code of Practice for Victims of Crime October 2015 England and Wales (Victims' Code). https:// assets.publishing.service.gov.uk/government/uploads/system/uploads/attachment_data/file/476900/ code-of-practice-for-victims-of-crime.PDF. Accessed 10 April 2020.

16. Collins, Jon. 2015. Restorative Justice in England and Wales: From the Margins to the Mainstream. Restorative Justice: An International Journal 3 (1): 129-134.

17. Conservative Party. 2010. Big Society Not Big Government: Building a Big Society. London: Conservative Party.

18. Council of Europe. 1999. Recommendation No. R. 19/1999 Concerning Mediation in Penal Matters. https://rm.coe.int/1680706970. Accessed 1 October 2020. 
19. Crawford, Adam. 2004. Involving Lay People in Criminal Justice. Criminology \& Public Policy 3 (4): 693-702.

20. Crawford, Adam, and Tim Newburn. 2002. Recent Developments in Restorative Justice for Young People in England and Wales: Community Participation and Representation. British Journal of Criminology 42 (3): 476-495.

21. Crawford, Adam, and Tim Newburn. 2003. Youth Offending and Restorative Justice: Implementing Reform in Youth Justice. Cullompton: Willan.

22. Crime and Courts Act 2013 England and Wales. http://www.legislation.gov.uk/ukpga/2013/22/ contents/enacted. Accessed 1 April 2020.

23. Crime and Disorder Act 1998 England and Wales. http://www.legislation.gov.uk/ukpga/1998/37/ contents. Accessed 11 June 2019.

24. Criminal Justice Act 1972 England and Wales. http://www.legislation.gov.uk/ukpga/1972/71/conte nts. Accessed 11 October 2019.

25. Criminal Justice Act 2003 England and Wales. http://www.legislation.gov.uk/ukpga/2003/44/conte nts. Accessed 12 April 2019.

26. Criminal Justice and Immigration Act 2008 England and Wales. http://www.legislation.gov.uk/ ukpga/2008/4/contents. Accessed 1 October 2019.

27. Crown Prosecution Service. 2014. Restorative Justice Legal Guidance. https://www.cps.gov.uk/ legal-guidance/restorative-justice. Accessed 1 October 2019.

28. Davey, Les. 2005. The Development of Restorative Justice in the UK: A Personal Perspective. Accessed 1 October 2019.https://www.iirp.edu/eforum-archive/the-development-of-restorativ e-justice-in-the-uk-a-personal-perspective. Accessed 17 October 2019.

29. Davis, Gwynn. 1992. Making Amends: Mediation and Reparation in Criminal Justice. London: Routledge.

30. Davis, Gwynn, Jacky Boucherat, and David Watson. 1988. Reparation in the Service of Diversion: The Subordination of a Good Idea. Howard Journal of Penal Reform 27 (2): 127-132.

31. Dignan, Jim. 1992. Repairing the Damage: Can Reparation be Made to Work in the Service of Diversion? British Journal of Criminology 32 (4): 453-472.

32. Duff, Antony. 2000. Punishment, Communication and Community. Oxford: Oxford University Press.

33. Edwards, Ian. 2010. Penal Policy Under the Coalition Government. https://www.criminallawandj ustice.co.uk/features/Penal-Policy-Under-Coalition-Government. Accessed 1 October 2019.

34. Etzioni, Amitai. 1993. The Spirit of Community. New York: Crown Books.

35. EU Directive 2012/29/EU Establishing Minimum Standards on the Rights, Support and Protection of Victims of Crime (Victims' Directive). https://eur-lex.europa.eu/legal-content/en/ TXT/?uri=CELEX\%3A32012L0029. Accessed 1 October 2019.

36. Fairclough, Norman. 2016. A Dialectical-Relation Approach to Critical Discourse Analysis in Social Research. In Methods of Critical Discourse Studies, ed. Ruth Wodak and Michael Meyer, 86-108. London: SAGE.

37. Foucault, Michel. 1970. The Order of Things: An Archaeology of the Human Sciences. New York: Pantheon Books.

38. Foucault, Michel. 1972. The Archaeology of Knowledge. New York: Pantheon Books.

39. Foucault, Michel. 1977. Discipline and Punish: The Birth of the Prison. New York: Random House.

40. Foucault, Michel. 1981. The Order of Discourse. Inaugural Lecture at the College de France, Given 2 December 1971. In Untying the Text. A Post-Structuralist Reader, ed. Robert Young, 48-78. London: Routledge \& Kegan Paul.

41. Foucault, Michel. 1982. The Subject and Power. In Michel Foucault: Beyond Structuralism and Hermeneutics, ed. Hubert Dreyfus and Paul Rabinow, 208-228. Chicago: University of Chicago Press.

42. Foucault, Michel. 1996. What is Critique? In Foucault Live: Collected Interviews 1961-1984, ed. Sylvain Lotringer, 41-81. New York: Semiotext(e).

43. Friedman, Rebekka, and Andrew Jillions. 2015. The Pitfalls and Politics of Holistic Justice. Global Policy 6 (2): 141-150.

44. Fry, Margery. 1951. Arms of the Law. London: Gollancz.

45. Garland, David. 2001. The Culture of Control: Crime and Social Order in Contemporary Society. Oxford: Oxford University Press. 
46. Garland, David. 2014. What is a "History of the Present"? On Foucault's Genealogies and Their Critical Preconditions. Punishment \& Society 16 (4): 365-384.

47. Gavrielides, Theo. 2007. Restorative Justice Theory and Practice: Addressing the Discrepancy. Helsinki: HEUNI.

48. Gibbs, Penelope and Amy Kirby. 2014. Judged by Peers? The Diversity of Lay Magistrates in England and Wales. http://www.icpr.org.uk/media/37787/HLWP_6_2014.pdf. Accessed 1 December 2019.

49. Giddens, Anthony. 1998. The Third Way: The Renewal of Social Democracy. Cambridge: Cambridge University Press.

50. Gray, Patricia. 2005. The Politics of Risk and Young Offenders' Experiences of Social Exclusion and Restorative Justice. British Journal of Criminology 45 (6): 938-957.

51. Halperin, David. 1995. Saint Foucault Towards a Gay Hagiography: Towards a Gay Hagiography. Oxford: Oxford University Press.

52. Harding, John. 1982. Victims and Offenders. London: Bedford Square Press.

53. HM Government. 2018. Victims Strategy. https://assets.publishing.service.gov.uk/government/ uploads/system/uploads/attachment_data/file/746930/victim-strategy.pdf. Accessed 20 May 2019.

54. HMIC, HMI Probation, HMI Prisons and the HMCPSI. 2012. Facing Up To Offending: Use of Restorative Justice in the Criminal justice System. https:/www.justiceinspectorates.gov.uk/hmicfrs/ media/facing-up-to-offending-20120918.pdf. Accessed 21 June 2019.

55. Home Office. 1986. Reparation: A Discussion Document. https://www.parliament.uk/depositedp apers?page $=1303 \&$ sort $=1$ (hardcopy only).

56. Home Office. 1997. No More Excuses White Paper. https://api.parliament.uk/historic-hansard/lords /1997/nov/27/youth-justice-white-paper. Accessed 2 November 2019.

57. Home Office. 2001. The Way Ahead. https://www.gov.uk/government/publications/criminal-justi ce-the-way-ahead. Accessed 20 May 2019.

58. Home Office. 2002. Justice for All White Paper. https://brdo.com.ua/wp-content/uploads/2016/01/ Justice-for-All-WPUK.pdf. Accessed 29 May 2019.

59. Home Office. 2003. Restorative Justice: The Government's Strategy. www.homeoffice.gov.uk/ docs2/restorativestrategy.pdf. Accessed 2 June 2019.

60. Home Office. 2004. Confident Communities in a Secure Britain Strategic Plan 2004-2008. https:// www.gov.uk/government/publications/the-home-office-strategic-plan-2004-to-2008. Accessed 20 May 2019.

61. Home Office. 2008. Youth Crime Action Plan. http://library.college.police.uk/docs/homeoffice/ ycap2009handbook.pdf. Accessed 20 May 2019.

62. Howarth, David. 2002. An Archaeology of Political Discourse? Evaluating Michel Foucault's Explanation and Critique of Ideology. Political Studies 50 (1): 117-135.

63. Hoyle, Carolyn, and Chris Cunneen. 2010. Debating Restorative Justice. London: Hart.

64. Hoyle, Carolyn, and Stephen Noguera. 2008. Supporting Young Offenders Through Restorative Justice: Parents as (In)appropriate Adults. British Journal of Community Justice 6 (3): 67-85.

65. Hoyle, Carolyn, Roderick Hill, and Richard Young. 2002. Proceed with Caution: An Evaluation of the Thames Valley Police Initiative in Restorative Cautioning. Oxford: Joseph Rowntree Foundation.

66. Hughes, Gordon. 2007. The Politics of Crime and Community. London: Palgrave.

67. Hulsman, Louk. 1986. Critical Criminology and the Concept of Crime. Contemporary Crises 10 (3-4): 63-80.

68. Johnstone, Gerry. 2011. Restorative Justice: Ideas, Values, Debates, 2nd ed. London: Routledge.

69. Johnstone, Gerry, and Tony Ward. 2010. Law and Crime. London: SAGE.

70. Jørgensen, Marianne, and Louise Phillips. 2002. Discourse Analysis as Theory and Method. London: Sage.

71. Labour Party. 1997. Labour Party Manifesto, General Election 1997. http://www.labour-party.org. uk/manifestos/1997/1997-labour-manifesto.shtml. Accessed 17 October 2019.

72. Lea, John, and Jock Young. 1984. What Is To Be Done About Law and Order-Crisis in the Eighties. London: Penguin.

73. Liebmann, Marian (ed.). 2000. Mediation in Context. London: Jessica Kingsley Publishers.

74. Liebmann, Marian. 2007. Restorative justice: How it Works. London: Jessica Kingsley Publishers.

75. Maglione, Giuseppe. 2017a. Embodied victims: An archaeology of the 'ideal victim' of restorative justice. Criminology \& Criminal Justice 17 (4): 401-417. 
76. Maglione, Giuseppe. 2017b. Communities at Large: An Archaeological Analysis of the 'Community’ Within Restorative Justice Policy and Laws. Critical Criminology 25 (3): 453-469.

77. Maglione, Giuseppe. 2018. Immature offenders. A critical history of the representations of the offender in restorative justice. Contemporary Justice Review 21 (1): 44-59.

78. Maglione, Giuseppe. 2019a. The political rationality of restorative justice. Theoretical Criminology 23 (4): 545-562.

79. Maglione, Giuseppe. 2019b. The Restorative Justice Apparatus: A Critical Analysis of the Historical Emergence of Restorative Justice. Social \& Legal Studies 28 (5): 650-674.

80. Maguire, Mike. 1985. Victims' Needs and Victim Services: Indications from Research. Victimology: An International Journal 10 (1-4): 539-559.

81. Marshall, Tony. 1996. The Evolution of Restorative Justice in Britain. European Journal on Criminal Policy and Research 4 (4): 21-43.

82. Marshall, Tony. 1999. Restorative Justice: An Overview. http://www.homeoffice.gov.uk/rds/pdfs/ occ-resjus.pdf. Accessed 17 October 2019.

83. Marshall, Tony, and Sally Merry. 1990. Crime and Accountability: Victim/Offender Mediation in Practice. London: HMSO.

84. Marshall, Tony, and Martin Walpole. 1985. Bringing People Together: Mediation and Reparation Projects in Great Britain. London: HMSO.

85. Masters, Guy, and David Smith. 1998. Portia and Persephone Revisited: Thinking About Feeling in Criminal Justice. Theoretical Criminology 2 (1): 5-27.

86. Mawby, R. 2016. Victim Support in England and Wales. The End of an Era? International Review of Victimology 22 (3): 203-221.

87. McEvoy, Kieran, et al. 2002. Introduction: Practice, Performance and Prospects for Restorative Justice. The British Journal of Criminology 42 (3): 469-475.

88. Mehozay, Yoav. 2018. From Offender Rehabilitation to the Aesthetic of the Victim. Social \& Legal Studies 27 (1): 97-113.

89. Miers, David, and Michael Semenchuk. 2005. Victim-Offender Mediation in England and Wales. In Victim-Offender Mediation with Youth Offenders in Europe: An Overview and Comparison of 15 Countries, ed. Anna Mestitz and Simona Ghetti, 23-46. Dordrecht: Springer.

90. Ministry of Justice. 2010. Breaking the Cycle: Effective Punishment, Rehabilitation and Sentencing of Offenders Green Paper. https://assets.publishing.service.gov.uk/government/uploads/system/uploads/ attachment_data/file/185947/green-paper-evidence-a.pdf. Accessed 2 May 2019.

91. Ministry of Justice. 2012a. Restorative Justice Action Plan for the Criminal Justice System in England and Wales. https://assets.publishing.service.gov.uk/government/uploads/system/uploads/attachment _data/file/217311/restorative-justice-action-plan.pdf. Accessed 12 January 2019.

92. Ministry of Justice. 2012b. Getting it right for Victims and Witnesses. https://consult.justice.gov.uk/digit al-communications/victims-witnesses/. Accessed 2 May 2019.

93. Ministry of Justice. 2012c. Swift and Sure Justice: The Government's Plans for Reform of the Criminal Justice System. https://assets.publishing.service.gov.uk/government/uploads/system/uploads/attac hment_data/file/217328/swift-and-sure-justice.pdf. Accessed 2 May 2019.

94. Ministry of Justice. 2013a. Restorative Justice Action Plan for the Criminal Justice System in England and Wales. https://assets.publishing.service.gov.uk/government/uploads/system/uploads/attachment _data/file/259782/restorative-justice-action-plan-2013.pdf. Accessed 2 May 2019.

95. Ministry of Justice. 2013b. Transforming Rehabilitation: A Summary of Evidence on Reducing Reoffending. https://www.gov.uk/government/publications/transforming-rehabilitation-a-summary-of-evide nce-on-reducing-reoffending. Accessed 2 April 2019.

96. Ministry of Justice. 2013c. Revised Code of Practice for Conditional Cautions-Adults. https://asset s.publishing.service.gov.uk/government/uploads/system/uploads/attachment_data/file/228971/97899 99098144.pdf. Accessed 23 May 2019.

97. Ministry of Justice. 2014. Restorative Justice Action Plan for the Criminal Justice System in England and Wales. https://assets.publishing.service.gov.uk/government/uploads/system/uploads/attachment_data/ file/375581/restorative-justice-action-plan-2014.pdf. Accessed 12 May 2019.

98. Morrison, Joe. 2011. Skepticism About Inductive Knowledge. In The Routledge Companion to Epistemology, ed. Sven Bernecker and Duncan Pritchard, 445-454. London: Routledge.

99. Muncie, John. 1999. Institutionalized Intolerance: Youth Justice and the 1998 Crime and Disorder Act. Critical Social Policy 19 (2): 147-175.

100. NACRO. 1997. Responsibility, Restoration and Reintegration: A New Three R's for Young Offenders. London: NACRO. 
101. Nixon, Paul. 1999. Family Group Conference Connections: Shared Problems and Joined Up Solutions. https://www.iirp.edu/eforum-archive/family-group-conference-connections-shared-problemsand-joined-up-solutions. Accessed 12 May 2019.

102. Novkov, Julie. 2011. Legal Archaeology. Political Research Quarterly 64 (2): 348-361.

103. O'Mahony, David, and Jonathan Doak. 2017. Reimagining Restorative Justice. Agency and Accountability in the Criminal Process. London: Bloomsbury.

104. Offender Rehabilitation Act 2014 England and Wales. http://www.legislation.gov.uk/ukpga/2014/11/ contents/enacted. Accessed 12 May 2019.

105. Parliamentary All-Party Penal Affairs Group. 1984. A New Deal for Victims. London: HMSO.

106. Pavlich, George. 2005. Governing Paradoxes of Restorative Justice. Portland: Glasshouse Press.

107. Powers of Criminal Courts Act 1973 England and Wales. http://www.legislation.gov.uk/ukpga /1973/62/enacted. Accessed 13 April 2019.

108. Reeves, Helen. 1984. The Victim and Reparation. Probation Journal 31 (4): 136-139.

109. Restorative Justice Council UK. 2015. Principles of Restorative Practice. https://restorativejustice.org. uk/resources/rjc-principles-restorative-practice. Accessed 12 June 2019.

110. Restorative Justice Council UK. 2015. Manifesto. https://restorativejustice.org.uk/sites/default/files/ news/files/RJC\%20Manifesto\%202015.pdf. Accessed 12 June 2019.

111. Restorative Justice Council UK. 2011. Best Practice Guidance for Restorative Practice. https://resto rativejustice.org.uk/sites/default/files/resources/files/Best\%20practice\%20guidance\%20for\%20restorat ive\%20practice\%202011.pdf. Accessed 1 January 2019.

112. Retzinger, Suzanne, and Thomas Scheff. 1996. Strategy for Community Conferences: Emotions and Social Bonds. In Restorative Justice: International Perspectives, ed. Burt Galaway and Joe Hudson, 315-336. Monsey: Criminal Justice Press.

113. Rock, Paul. 1990. Helping Victims of Crime: The Home Office and the Rise of Victim Support in England and Wales. Oxford: Oxford University Press.

114. Rock, Paul. 2004. Constructing Victims' Rights. Oxford: Oxford University Press.

115. Rock, Paul. 2005. Victims Rights in England and Wales at the Beginning of the Twenty-first Century. In Understanding Social Change, ed. Anthony Heath, John Ermisch, and Duncan Galli, 319-350. Oxford: Oxford University Press.

116. Shapland, Joanna. 1984. Victims, the Criminal Justice System and Compensation. British Journal of Criminology 24 (2): 131-149.

117. Shapland, Joanna, Jon Wilmore, and Peter Duff. 1985. Victims in the Criminal Justice System. Aldershot: Gower.

118. Shapland, Joanna, et al. 2006. Restorative Justice in Practice. The Second Report from the Evaluation of Three Schemes. https://www.shef.ac.uk/polopoly_fs/1.783!/file/RestorativeJustice2ndReport.pdf. Accessed 12 June 2019.

119. Sim, Joe. 2010. The Toxic Legacy of New Labour. https://www.crimeandjustice.org.uk/sites/crime andjustice.org.uk/files/09627250903570005.pdf. Accessed 12 January 2020.

120. Skinns, David. 2016. Coalition Government Penal Policy 2010-2015: Austerity, Outsourcing and Punishment. London: Palgrave.

121. Smith, David, Harry Blagg, and Nick Derricourt. 1988. Mediation in South Yorkshire. British Journal of Criminology 28 (3): 378-395.

122. The Children Act 1989 England and Wales. http://www.legislation.gov.uk/ukpga/1989/41/contents. Accessed 12 January 2019.

123. UN. 1985. Declaration of Basic Principles of Justice for Victims of Crime and Abuse of Power. https:// www.un.org/en/genocideprevention/documents/atrocity-crimes/Doc.29_declaration\%20victims\%20cri me\%20and\%20abuse\%20of\%20power.pdf. Accessed 12 June 2019.

124. UN. 2002. Basic Principles on the Use of Restorative Justice Programmes in Criminal Matters. https ://www.un.org/ruleoflaw/blog/document/basic-principles-on-the-use-of-restorative-justice-progr ammes-in-criminal-matters/. Accessed 12 June 2019.

125. Van Ness, Daniel, and Heather Strong. 2015. Restoring Justice, 5th ed. Cincinnati: Anderson.

126. Veyne, Paul. 2010. Foucault. Cambridge: Polity Press.

127. Victim Support. 2001. Criminal Neglect No Justice Beyond Criminal Justice. https://www.victimsupp ort.org.uk/sites/default/files/Criminal\%20neglect\%20report.pdf. Accessed 12 June 2019.

128. Von Hirsch, Andrew, et al. (eds.). 2003. Restorative Justice and Criminal Justice: Competing or Reconcilable Paradigms?. London: Hart.

129. Walgrave, Lode. 2017. Restorative Justice is Not a Panacea Against All Social Evils. In Critical Restorative Justice, ed. Ivo Aertsen and Brunilda Pali, 95-110. London: Hart. 
130. Wright, Martin. 1977. Nobody Came: Criminal Justice and the Needs of Victims. Howard Journal 16 (1): $22-31$.

131. Wright, Martin. 1982. Making Good: Prisons, Punishment, and Beyond. London: Burnett Books.

132. Wright, Martin. 1996. Justice for Victims and Offenders. Winchester: Waterside Press.

133. Wright, Martin. 2002. The Court as Last Resort. Victim-Sensitive, Community-based Responses to Crime. British Journal of Criminology 42 (3): 654-667.

134. Wright, Martin, and Burt Galaway (eds.). 1989. Mediation and Criminal Justice: Victims, Offenders and Community. London: SAGE.

135. Youth Justice Board. 2006. Developing Restorative Justice: An Action Plan. London: Youth Justice Board.

136. Youth Justice and Criminal Evidence Act 1999 England and Wales. http://www.legislation.gov.uk/ ukpga/1999/23/contents. Accessed 12 June 2019.

137. Zehr, Howard. 1985. New Perspectives of Crime and Justice. Valparaiso: MCC.

138. Zehr, Howard. 2002. The Little Book of Restorative Justice. Intercourse: Good Books.

139. Zehr, Howard. 2005. Changing Lenses: A New Focus for Crime and Justice, 3rd ed. Scottdale: Herald Press.

140. Zernova, Margarita. 2007. Restorative Justice: Ideals and Realities. Abington: Ashgate.

Publisher's Note Springer Nature remains neutral with regard to jurisdictional claims in published maps and institutional affiliations. 